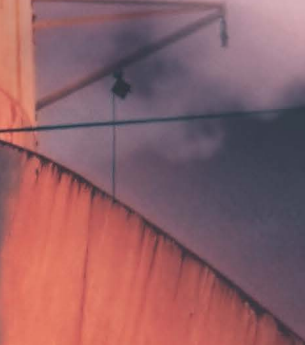

African perspectives on selected marine, maritime and

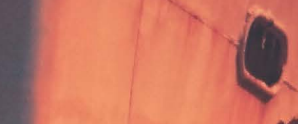

)
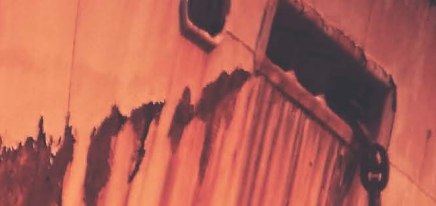

:
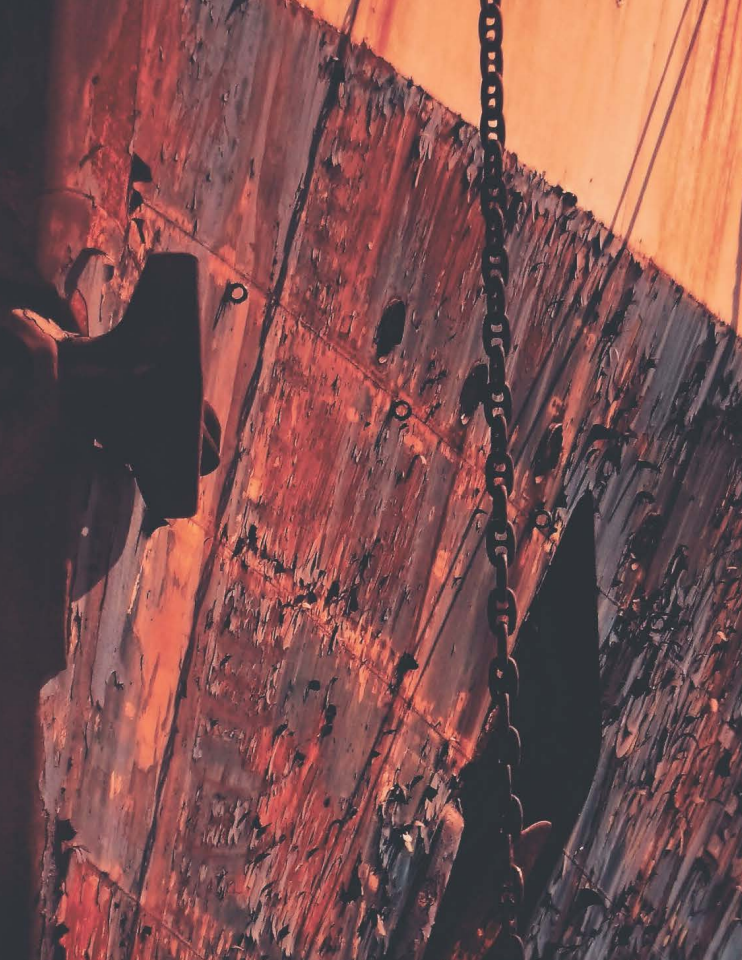

Patrick Vrancken \& Char! Hugo (Eds)

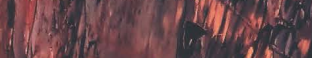

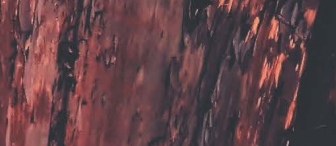

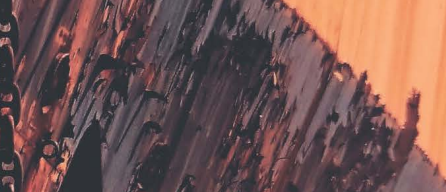




\title{
SANCTIONS, SHIPS, INTERNATIONAL SALES AND SECURITY OF PAYMENT
}

\author{
CHARL HUGO
}

HENNIE STRYDOM ${ }^{\star \star}$

* Professor of Banking Law and Director of the Centre for Banking Law, University of Johannesburg.

** Professor in Public International Law and holder of the NRF Research Chair in International Law, University of Johannesburg. 


\section{INTRODUCTION}

In furtherance of real (or perhaps perceived) world and national security, sanctions - in more recent times, especially targeted financial sanctions - have emerged as a powerful weapon to combat international crime. As an enforcement measure under article 41 of the United Nations (UN) Charter, targeted financial sanctions are a result of the suffering to which the Iraqi population was subjected under the UN's conventional economic sanctions regime imposed on Iraq following Saddam Hussein's unlawful military invasion and occupation of Kuwait in 1990. This blunt measure made no distinction between the guilty and the innocent or between the delinquent leaders and the general population. To mitigate against such consequences, targeted or smart sanctions against specific individuals and entities became the preferred enforcement measure since 1999 with the adoption of United Nations Security Council (UNSC) resolution 1267. ${ }^{1}$ This practice, which has become even more pronounced with the adoption of counter-terrorism measures after $9 / 11,{ }^{2}$ is currently also employed by individual States acting on their own against delinquent members of the international community.

Today, such sanctions may, in the first place, take the form of international sanctions arising from decisions of the UNSC in terms of which Member States are required to enact legislation or to adopt other measures to implement these sanctions. For this reason, the chapter starts with an overview of the UN sanctions regime applicable to the subject-matter of the chapter to which States are required to give effect by means of domestic laws and policies.

In South Africa, this is done, inter alia, through the Protection of Constitutional Democracy against Terrorist and Related Activities Act (POCDATARA) ${ }^{3}$ and the Financial Intelligence Centre Act (FICA). ${ }^{4}$ The POCDATARA ${ }^{5}$ sanctions, which

1 See also White and Abass "Countermeasures and sanctions" in Evans (ed) International Law (2018) 521 542, 543; Shaw International Law (2017) 957.

2 See, inter alia, Strydom "Counter-terrorism measures and human rights" in Maluwa, Du Plessis, and Tladi (eds) The Pursuit of a Brave New World: Essays in Honour of John Dugard (2017) 395.

333 of 2004 .

438 of 2001.

5 See Hugo and Spruyt "Money laundering, terrorist financing and financial sanctions: South Africa's response by means of the Financial Intelligence Centre Amendment Act" 2018 TSAR 227249 et seq. 
are restricted to the domain of terrorism, prohibit any person from dealing with property that is associated with terrorism or persons or organisations that carry out such acts. ${ }^{6}$ The wider-ranging relevant provisions of FICA were introduced by the Financial Intelligence Centre Amendment Act and eventually came into force on 1 April 2019, somewhat later than the other provisions of the amending legislation, apparently because it took time to develop and put into place the mechanisms required for their implementation. ${ }^{7}$ South Africa also adopted the Application of Resolutions of the Security Council of the United Nations Act, ${ }^{8}$ which provides, in section 1, for the domestic application of UNSC resolutions by way of proclamation in the Government Gazette. However, the Act has never been put into force and effect.

In the second place, as indicated above, sanctions may be imposed independently of the UN by means of national legislation of a particular country. In this respect, we restrict ourselves to the sanctions imposed by the United States of America (US), which are probably the most important for purposes of this contribution. The prominence of US sanctions increased dramatically in the wake of the terrorist attacks of $9 / 11 .{ }^{9}$ We refer here to the sanctions administered by the Office of Foreign Assets Control (OFAC) of the US Treasury, the official website of which states its role as follows:

"The Office of Foreign Assets Control ('OFAC') of the US Department of the Treasury administers and enforces economic and trade sanctions based on US foreign policy and national security goals against targeted foreign countries and regimes, terrorists, international narcotics traffickers, those engaged in activities related to the

6 See ss 3 and 4.

7 See the Financial Intelligence Centre Amendment Act 1 of 2017, and, on the implementation of the sanctions provisions, Financial Intelligence Centre Notice by the Director in terms of Section 26A(3) of the Financial Intelligence Centre Act, 2001 https://www.fic.gov.za/Documents/Website\%20Notice\%20by\%20the\%20 Director\%20-\%201\%20April\%202019.pdf (28-8-2020). See further Financial Intelligence Centre Roadmap for the Short Term Implementation of the Financial Intelligence Centre Amendment Act, 2017 par 1.8. It was, however, initially envisaged that the provisions would have come into operation towards the end of 2018. See also Spruyt "The Financial Intelligence Centre Amendment Act and the application of a risk-based approach" in Hugo and Du Toit (eds) Annual Banking Law Update (2017) 19 n 8.

8172 of 1993.

9 See Carter and Farha "Overview and operation of the evolving US financial sanctions, including the example of Iran” Proceedings of the Annual Meeting (American Society of International Law) Vol 107 (2013) 315 n 2 citing Uniting and Strengthening America by Providing Appropriate Tools Required to Intercept and Obstruct Terrorism (USA Patriot Act) 2001. 
proliferation of weapons of mass destruction, and other threats to the national security, foreign policy or economy of the United States". ${ }^{10}$

To give effect to these sanctions, OFAC published and regularly updates a list of "specially designated nationals" (SDNs) who are targeted. ${ }^{11}$ In this respect, the OFAC website states:

"As part of its enforcement efforts, OFAC publishes a list of individuals and companies owned or controlled by, or acting for or on behalf of, targeted countries. It also lists individuals, groups, and entities, such as terrorists and narcotics traffickers designated under programs that are not country-specific. Collectively, such individuals and companies are called 'Specially Designated Nationals' or 'SDNs.' Their assets are blocked and U.S. persons are generally prohibited from dealing with them"12.

The SDNs include a large number of natural persons and companies (including import and export companies, shipping companies and banks) tied to, inter alia, Iran, Syria, North Korea and, closer to our borders, Zimbabwe. ${ }^{13}$ A later addition to the list, and especially relevant for the purposes of this contribution, is a large number of vessels (ships and aircraft). ${ }^{14}$

All "U.S. persons" must comply with the OFAC regulations. "U.S. persons" include:

"all U.S. citizens and permanent resident aliens regardless of where they are located, all persons and entities within the United States, all U.S. incorporated entities and their

10 https://www.treasury.gov/resource-center/sanctions/Pages/default.aspx (19-3-2019).

11 https://www.treasury.gov/ofac/downloads/sdnlist.pdf (26-2-2019). The list is updated regularly - the one referred to is dated 19 March 2019. There is much activity in relation to the imposition and relaxation of OFAC sanctions. See, for example, the overview by Boscariol, Briscoe, Goodale, Harwig, Meyer, Stagg and Ward "Export controls and economic sanctions" in The Year in Review An Annual Publication of the ABA/Section of International Law (Spring 2016) 27 34-39.

12 https://www.treasury.gov/resource-center/sanctions/SDN-List/Pages/default.aspx (19-3-2019). The italics are ours.

13 See, for one example that has received attention in South African courts (refer to $\mathrm{n} 16$ below in this regard), the OFAC SDN List (n 11) which, on page 271, contains the following inscription: "BREDENKAMP, John (a.k.a. BREDENKAMP, John A.; a.k.a. BREDENKAMP, John Arnold), Thetford Farm, P.O. Box HP86, Mount Pleasant, Harare, Zimbabwe; 10 Montpelier Square, London SW7 1JU, United Kingdom; Hurst Grove, Sanford Lane, Hurst, Reading, Berkshire RG10 0SQ, United Kingdom; Middleton House, Titlarks Hill Road, Sunningdale, Ascot, Berkshire SL5 0JB, United Kingdom; New Boundary House, London Road, Sunningdale, Ascot, Berkshire SL5 ODJ, United Kingdom; Mapstone House, Mapstone Hill, Lustleigh, Newton Abbot, Devon TQ13 9SE, United Kingdom; Dennerlei 30, Schoten, Belgium; 62 Chester Square, London, United Kingdom; DOB 11 Aug 1940; citizen Netherlands; alt. citizen Zimbabwe; alt. citizen Suriname; Passport ND1285143 (Netherlands); alt. Passport Z01024064 (Netherlands); alt. Passport Z153612 (Netherlands); alt. Passport 367537C (Suriname) (individual) [ZIMBABWE]".

14 https://www.treasury.gov/resource-center/sanctions/SDN-List/Pages/default.aspx (19-3-2019) 1238 et seq. 
foreign branches [as well as in the case of certain sanctions] ... foreign subsidiaries owned or controlled by U.S. companies ... [and] foreign persons in possession of U.S.origin goods ..." ${ }^{15}$

Targeted sanctions relating to ships impact upon international sales mainly in two manners. First, they may affect directly the free movement of ships by denying them access to particular harbours, being refuelled or from offloading or transhipping goods on board as well as subjecting the ship and its cargo to seizure and asset freezes. Secondly, they may impact indirectly by preventing financial institutions from processing payment in respect of transactions involving a targeted ship. We deal with this aspect in more detail below. In the case of US sanctions, banks in other countries, which, as a cold legal fact, may not technically be bound by the US legislation in this regard, will mostly also refuse to process or make a payment on the basis of strong business and reputational considerations. ${ }^{16}$ The impact of sanctions on the ability of banks to make payment in international sale transactions is particularly evident in letter-of-credit practice - the dominant method of payment when security of payment becomes a real concern. The letter of credit has developed over the past century ${ }^{17}$ into a remarkably secure instrument ensuring not only that the seller is paid, but also that the buyer receives the goods contracted for. ${ }^{18}$

Targeted financial sanctions and security of payment in international sales to put it mildly - experience a very difficult co-existence. Against the background of this general introduction, we deal first with sanctions affecting the movement

15 https://www.treasury.gov/resource-center/faqs/Sanctions/Pages/faq_general.aspx (19-3-2019).

16 See, for example, the litigation in South Africa between Bredenkamp (the SDN referred to in note 13 above) and Standard Bank in which the bank went to great lengths to close the account of Bredenkamp for business and reputational reasons arising from his status as listed individual: Breedenkamp v Standard Bank of South Africa Ltd 2009 5 SA 304 (GSJ); Breedenkamp v Standard Bank of South Africa Ltd 20096 SA 277 (GSH); and Bredenkamp v Standard Bank of South Africa Ltd 20104 SA 468 (SCA).

17 Much has been written on the historical development of letters of credit. See in this regard Hugo "The development of documentary letters of credit as reflected in the Uniform Customs and Practice of Documentary Credits" 1993 SA Merc LJ 44 et seq. Ground-breaking early work includes that of Biro "Das Akkreditivgeschäft der Merchant Bankers" 1959 Oestereichische Bank Archiv 408 et seq; Ritter "Vom Akkreditiv" 1921 Hanseatische RechtsZeitschrift 609; Hershey "Letters of Credit" 1918-1919 Harvard LR 1; McCurdy "Commercial Letters of Credit" 1921-1922 Harvard LR 539 et seq, 715 et seq; Kozolchyk "The legal nature of the irrevocable commercial letter of credit" 1965-1966 American Journal of Comparative Law 395; and Ellinger Documentary Letters of Credit (1970) 26 et seq.

18 Sharrock (ed) The Law of Banking and Payment in South Africa 403-404. 
of ships (and related issues). We then deal with their impact on payment (especially in the letter-of-credit context) before formulating some conclusions.

\section{SELECT UN SANCTIONS LINKED TO TRANSACTIONS INVOLVING TARGETED SHIPS AND THEIR CARGO}

The UN sanctions regime against the Democratic People's Republic of Korea (DPRK) was adopted in response to the country's decision, in 1993, to withdraw from the 1968 Treaty on the Non-proliferation of Nuclear Weapons ${ }^{19}$ and its subsequent nuclear weapon tests coupled with the test-launching of intercontinental ballistic missiles in blatant disregard for UNSC resolutions demanding the suspension of all such activities. ${ }^{20}$ Between 2006 and 2017, a pattern of adjustment and expansion of sanctions developed, prompted by the DPRK regime's obstinate determination to develop and test nuclear weapons and ballistic missiles in clear violation of UNSC resolutions that considered such conduct a threat to international peace and security.

As the sanctions regime expanded and became more stringent over time, the DPRK shipping industry became a prime target. This was necessary in view of ensuing sanction-evasion practices in the form of the re-designation of vessels, the changing of their identity numbers and names, and transhipments of cargo containing listed items. With 240 merchant ships under its jurisdiction, the opportunities for sanctions evasion by the DPRK regime and its targeted officials were manifold. Over time, the evasion practices also attracted the attention of the Panel of Experts established by UNSC resolution 1874 (2009) to assist the Security Council Sanctions Committee to carry out its mandate as specified in resolution 1718 (2006) in respect of the supply, sale or transfer by the DPRK of certain listed materials, goods or equipment and the export thereof by UN Member States to the DPRK. In its 2018 report, the Panel concluded as follows:

\footnotetext{
"In addition to ongoing violations and increasingly sophisticated evasion practices, the Panel's latest investigations show that the Democratic People's Republic of Korea is already flouting the most recent resolutions by exploiting global oil supply chains,
}

19729 UNTS 161, (1968) 7 ILM 889. Adopted: 01-07-1968; EIF: 05-03-1070.

20 See inter alia UNSC resolution 1695 (2006) par 2. 
complicit foreign nationals, offshore company registries and the international banking system. The Panel investigated illicit ship-to-ship transfers of petroleum comprising a multi-million-dollar business that is driving an international network of brokers and ship charterers as well as unwitting global commodity trading companies and oil suppliers. In tandem, the Democratic People's Republic of Korea continued to export almost all the commodities prohibited in the resolutions, generating nearly $\$ 200$ million in revenue between January and September 2017. In continuing its illicit coal exports, the country combined deceptive navigation patterns, signals manipulation, trans-shipment and fraudulent documentation to obscure the origin of the coal". ${ }^{21}$

The salient features of the UN's sanction regime as they relate to the subjectmatter of this contribution fall into two categories, namely restrictions on the movement of ships and restrictions on certain financial transactions. Both are aimed at preventing the supply, sale or transfer of certain materials, equipment, goods, technology or weapons which could contribute to the DPRK's nuclear-related, ballistic missile-related or other weapons-of-mass-destruction-related programme.

Restrictions on the movement of ships take, in the first instance, the form of a duty on Territorial States to inspect all cargo to and from the DPRK when there are reasonable grounds to believe that the cargo contains items prohibited by the UNSC's sanctions regime. ${ }^{22}$ This also applies to vessels on the high seas, which must be inspected with the consent of the Flag State or which, when the Flag State does not give its consent, must be directed by the Flag State to proceed to a convenient port for inspection by the Territorial State. ${ }^{23}$ Prohibited items identified during inspections are subject to seizure and disposal by the Inspecting State. ${ }^{24}$ On the same grounds, the UN Member States and their nationals are prohibited from providing bunkering services, such as the provision of fuel or supplies or other services, to DPRK vessels. ${ }^{25}$

Following another nuclear test by the DPRK on 6 January 2016, the measures imposed by resolution 1718 (2006) and 1874 (2009) were to apply

21 UN Doc S/2018/171 (5 March 2018).

22 UNSC resolution 1874 (2009) par 11.

23 par 13.

24 par 14.

25 par 17. 
also to the shipment of items to or from the DPRK for repair, servicing, testing, reverse-engineering and marketing, regardless of whether ownership or control is transferred, and to any individual travelling for the purposes of carrying out these activities. ${ }^{26}$ Resolution 2270 prohibits the leasing or chartering of vessels or aircraft by nationals of, or residents in, Member States, or by any other designated person or entity, to the DPRK. It also calls upon Member States to de-register any vessel that is owned, operated or crewed by the DPRK and not to register any such vessel that is de-registered by another Member State pursuant to this resolution. ${ }^{27}$ Member States are also prohibited from allowing into their ports any vessel in respect of which the Member State has information that provides reasonable grounds to believe that the vessel is owned or controlled by a designated individual, or contains cargo the supply, sale, transport or export of which is prohibited. ${ }^{28}$ In this regard, Annex III to the resolution contains a list of 31 vessels that are considered "economic assets" subject to the asset-freeze obligation under the PDRK sanctions regime.

Another nuclear test in September 2016 caused the UNSC to further tighten and expand on the sanctions already imposed. For instance, the chartering and leasing prohibition in paragraph 19 of resolution 2270 was made applicable to "all leasing, chartering or provision of crew services to the DPRK without exception" unless approved by the Security Council Committee in advance. ${ }^{29}$ Moreover, when the Committee has reasonable grounds to believe that vessels are or have been related to the DPRK's prohibited weapons programmes, it may require the following steps to be taken against designated vessels: (a) that the Flag State de-flags the vessel; (b) that the Flag State instructs the vessel to proceed to a port identified by the Committee, in coordination with the Port State; (c) that all UN Member States prohibit a designated vessel from entering their ports unless for emergency reasons or under direction of the Committee; and (d) that the vessel becomes subject to asset freeze measures. ${ }^{30}$ Further adjustments followed in

\footnotetext{
26 SC resolution 2270 (2016) par 7.

27 par 19, 20.

28 par 22.

29 SC resolution 2321 (2016) par 8.

30 par 12.
} 
2017, in response to yet another nuclear test on 2 September 2017, determining that failure by a Flag State to cooperate with the inspection of its vessels on the high seas would result in the Committee designating the vessel in question for the measures imposed by the UNSC in resolutions 1718 (2006) and 2321 (2016). In such instances, the Flag State is under an obligation to de-register the vessel immediately. ${ }^{31}$ Under this resolution, UN Member States must also prohibit their nationals or persons or entities under their jurisdiction, as well as vessels flying their flag, from facilitating or engaging in ship-to-ship transfers to or from DPRK-flagged vessels of any prohibited goods or items that are being supplied, sold or transferred to or from the DPRK. ${ }^{32}$

As indicated above, restrictions on financial transactions are another salient feature of the sanctions regime against the DPRK. Targeted in this regard is the provision of financial services through or from Member States' territories, or to or by their nationals or entities, that could contribute to the DPRK's prohibited weapons programmes. In addition, financial or other assets or resources that are associated with such programmes fall under the Member State's freezing of assets obligations. ${ }^{33}$ The resolution also extends the imposition of financial sanctions to international financial and credit institutions by interdicting the entering by such institutions into new commitments for grants, financial assistance or concessional loans to the DPRK. ${ }^{34}$ Also affected is public financial support for trade with the DPRK, including the granting of export credits, guarantees or insurance to Member States' nationals or entities involved in such trade. ${ }^{35}$

In its March 2013 resolution, ${ }^{36}$ following another nuclear test by the DPRK on 12 February 2013, the UNSC more fully addressed the violation of the DPRK sanctions regime. Already in the preamble the resolution urged Member States to apply the Financial Action Task Force's (FATF) new interpretative note on recommendation 7 on customer due diligence and record keeping regarding

\footnotetext{
31 UNSC resolution 2375 (2017) par 8.

32 par 11.

33 UNSC resolution 1874 (2009) par 18.

34 par 19.

35 par 20

36 UNSC resolution 2094 (2013).
} 
targeted financial sanctions in relation to non-proliferation. ${ }^{37}$ Furthermore, the resolution included brokering or other intermediate services, ${ }^{38}$ bulk cash payments ${ }^{39}$ or any other financial or other assets or resources that could contribute to the DPRK's prohibited weapons programmes as activities that will fall under the DPRK sanctions regimes. For the same reason, the resolution prohibits the opening of new branches, subsidiaries or representative offices of DPRK banks in the territories of Member States, as well as the establishing of new joint ventures or correspondent relationships with banks in their jurisdiction if they have information or have reasonable grounds to believe that such financial services could contribute to the DPRK's nuclear or ballistic-missile programme. ${ }^{40}$ Further obligations were imposed in 2016 to the effect that UN Member States were to interdict their nationals, and persons and entities under their jurisdiction from providing insurance or re-insurance services to vessels owned, controlled or operated by the DPRK unless a vessel is used exclusively for humanitarian purposes and exempted in advance by the Security Council's Sanctions Committee. ${ }^{41}$

\section{THE IMPACT OF SANCTIONS ON PAYMENT (ESPECIALLY BY LETTER OF CREDIT)}

\section{The letter of credit as payment method}

A letter of credit (also known as a documentary credit) is essentially an undertaking by a bank to pay the beneficiary of the letter of credit provided certain conditions are met. ${ }^{42}$ The underlying contract is normally an international contract of sale in which the buyer and seller have agreed to payment by letter of credit. The buyer, to give effect to the payment clause of the contract of sale, requests (mandates) a bank (typically the buyer's own bank - the issuing bank) to issue a letter of credit in favour of the seller (the beneficiary of the letter of

37 available at https://eurasiangroup.org/Methodology/eng/note/7/ (27-6-2018).

38 UNSC Resolution 2094 par 7.

39 par 11.

40 par 12.

41 UNSC resolution 2321 (2016) par 22.

42 Sharrock (n 18) 403. 
credit). ${ }^{43}$ The mandate given by the buyer also contains the conditions that need to be met by the seller in order to be paid by the bank. These conditions are invariably documentary. In other words, in order to be paid by the bank, the seller will have to provide certain stipulated documents. ${ }^{44}$ These documents must comply strictly with the terms of the letter of credit issued by the bank (which in turn should reflect exactly the instructions of the buyer in the mandate). If the seller, accordingly, presents conforming documents, it will be entitled to payment in terms of the letter of credit and, if the bank has paid against conforming documents, it will be entitled to reimbursement in terms of the contract of mandate. ${ }^{45}$

It is important to take note of the fact that letters of credit are almost always issued and dealt with in accordance with rules drafted under the auspices of the Banking Commission of the International Chamber of Commerce (ICC), namely the Uniform Rules and Practice for Documentary Credits (UCP). ${ }^{46}$ It is important to realise that these rules have no higher status than contractually incorporated terms of contract. The Banking Commission of the ICC, moreover, provides continuous guidance relating to letter-of-credit practice in the form of opinions (written and published answers to questions mostly from banks) and formal guidance notes (which are also published). ${ }^{47}$

The presentation of many different documents can be required by the letter of credit. Amongst those most often encountered are the commercial invoice, the transport document (for example a marine bill of lading or a combined transport document), the insurance document and any of a number of certificates, such as a

43 Sharrock (n 18) 404-405, 407.

44 408-409.

45409.

46 For a more detailed analysis of the history and role of the ICC and the UCP 600, see Hugo "Letters of credit and demand guarantees: a tale of two sets of rules of the International Chamber of Commerce" 2017 TSAR 1.

47 Hugo (n 46) 13. One such guidance paper dating back to 2014, which is especially relevant in this context and is considered in more detail below, is the "Guidance Paper on the Use of Sanctions Clauses in Trade Financerelated Instruments subject to ICC Rules” Document 470/1238 (https://cdn.iccwbo.org/content/uploads/ sites/3/2014/08/Guidance-Paper-on-The-Use-Of-Sanctions-Clauses-In-Trade-Finance-Related-InstrumentsSubject-To-ICC-Rules.pdf). 
certificate of inspection, a certificate of quality and a certificate of origin. ${ }^{48}$ These documents contain much information. Apart from an accurate description of the goods and the price, the commercial invoice may well indicate who the consignor or exporter is, who the consignee is (and the buyer if it is someone other than the consignee), the country of origin of the goods, the country of destination of the goods, the ports of loading and discharge of the goods and the names of contact persons of the buyer and the consignor. Much of this information may also be replicated on the bill of lading which, in addition, will also indicate the name of the carrier and - of particular importance for the purpose of this contribution the name and IMO registration number of the vessel. ${ }^{49}$ The insurance document will, furthermore, indicate who the insurer is and, likewise, the certificates will identify their issuers as well as the information certified (such as the quality or origin of the goods) and the date and place where this was done.

The bank's undertaking in a letter of credit has a very special legal status: it is independent or autonomous. This means that the question whether or not the bank is obliged to pay the beneficiary is determined solely with reference to the letter of credit and not with reference to the contract of sale (the underlying contract) ${ }^{50}$ or the mandate (from which the bank's right to reimbursement

48 These are the most common documents encountered in documentary sales (see Sharrock (n 18) 395). The UCP 600 contains provisions relating only to commercial invoices (a 18), transport documents (aa 19-27) and insurance documents (a 28). However, the parties are free to contract for any document they may wish to have. See also, specifically in relation to the different documents encountered in the sanctions context, Strong and Herd "Letter of credit payment \& sanctions" http://www.strongandherd.co.uk/international-trade-articles/article-letters-of-creditsanctions/ (21-3-2019).

49 The background and role of the IMO number is stated as follows on the webpages of More Than Shipping ("Lloyd's and IMO numbers for shipping vessels" https://www.morethanshipping.com/lloyds-imo-numbervessels/ (21-3-2019)): “The International Maritime Organization (IMO) number is a unique reference for ships and for registered ship owners and management companies. IMO numbers were introduced under the SOLAS Convention to improve maritime safety and security and to reduce maritime fraud. The ship number consists of the three letters 'IMO, followed by a unique seven-digit number assigned to sea-going merchant ships under the International Convention for the Safety of Life at Sea (SOLAS). In 1987, the IMO adopted Resolution A.600(15), 'aimed at enhancing maritime safety, and pollution prevention and to facilitate the prevention of maritime fraud' by assigning to each ship a permanent identification number which would continue despite any subsequent change in the vessel's name, ownership or flag". (The italics are ours.)

50 Phillips $v$ Standard Bank of South Africa Ltd 19853 SA 301 (WLD) 303; Loomcraft Fabrics CC v Nedbank Ltd 19961 SA 812 (A) 815. For analyses of the independence principle in general in letter-of-credit practice, see Sharrock (n 18) 422 et seq (condensed) and Enonchong The Independence Principle of Letters of Credit and Demand Guarantees (2011) (comprehensive). See also art 4 of the UCP 600. 
arises). ${ }^{51}$ This is a very strong rule of letter-of-credit law. There are exceptions to the rule, the best-established being fraud by the beneficiary. However, reliance on the exceptions is seldom successful. ${ }^{52}$ Certainty of payment is regarded as a dominant policy consideration in international trade. This has led courts to invoke the vivid imagery of the flowing of "lifeblood" and the avoidance of "thrombosis" by interfering with the passage of money. ${ }^{53}$

The above explanation of the operation of payment by letter of credit takes account only of the minimum number of parties involved in the transaction, namely the buyer, the seller and the issuing bank. Normally, however, more banks are involved. It is necessary to deal briefly with their respective roles. ${ }^{54}$

Typically, the issuing bank will not communicate the letter of credit directly to the beneficiary. It will instruct another bank in the seller's country to do so. This bank is known as the advising bank. The advising bank acts as a mere messenger on the instructions of the issuing bank which, almost invariably today, it will receive by means of SWIFT communication..$^{55}$ The advising bank accordingly does not make any payment undertaking.

Moreover, the beneficiary will not normally be required to deliver the documents to the issuing bank, which is typically in another country. The letter of credit communicated (advised) to the beneficiary will nominate a bank in the beneficiary's country that will receive the documents and effect payment on

51 art 4 of the UCP 600. See also Sharrock (n 18) 422; Hugo The Law relating to Documentary Credits from a South African Perspective with Special Reference to the Position of the Legal Position of the Issuing and Confirming Banks (1996 thesis Stell) par 6.2.4 and 6.5.2.

52 See the Phillips case (n 50) 303 and the Loomcraft case (n 50) 817. In the latter case, Scott AJA stated that, although the onus of proving fraud was the "ordinary civil one", he stressed that it "will not lightly be inferred" (817G). For a South African case in which fraud was successfully raised, see Group Five Construction (Pty) Ltd) v Member of the Executive Council Public Transport Roads and Works Gauteng 2015 (5) SA 26 (GJ).

53 RD Harbottle (Mercantile) Ltd v National Westminster Bank Ltd 19772 All ER 862 (QB) 870b-d ("lifeblood") and Intraco Ltd v Notis Shipping Corporation (The Bhoja Trader) 19812 Lloyd's Rep 256 (CA) 257 (both "lifeblood" and "thrombosis").

54 For a more detailed overview of the role of the different banks, see Sharrock (n 18) 404-414 and 430-433. See also art 2,7-9,12, 13 and 38 of the UCP 600.

55 The acronym stands for the "Society for Worldwide Interbank Financial Telecommunications" based in Belgium. See Carter and Farha (n 9) 316, who explain that it provides "just a communication system" (that is to say that it has no direct settlement function) but, by providing a "common language" for payment instructions for financial institutions around the world" it is "vital to the settlement of international payments". 
behalf of the issuing bank. ${ }^{56}$ This nominated bank, too, acts as mandatary of the issuing bank and does not itself make any payment undertaking. Hence, when it pays, it discharges only the issuing bank's obligation to pay. Once it has paid, the nominated bank is entitled to be reimbursed by the issuing bank provided, of course, the documents presented to it by the beneficiary were conforming (in other words in strict compliance with the requirements of the letter of credit).

In certain instances, especially when either the issuing bank or the country in which the issuing bank is located is not trusted by the beneficiary, the latter may require that the letter of credit be confirmed by a bank in its own country or in another reputable country. In this case, another bank, the confirming bank, will become involved. A confirming bank may play the role of both advising and nominated bank (thereby replacing them), but this is not necessarily the case. Its main purpose, however, is to confirm the letter of credit, that is to add its own independent undertaking to that of the issuing bank. Hence, the beneficiary of a confirmed letter of credit has an independent claim against both the issuing bank and the confirming bank under the letter of credit. Provided the beneficiary tenders conforming documents, it can therefore enforce payment against either of these banks.

In the event of the beneficiary being a middleman, that is the beneficiary itself is purchasing the goods from a supplier or manufacturer in order to resell them, a transferable letter of credit may be used. A transferable letter of credit enables the beneficiary to pay its supplier by utilising the letter of credit issued in its favour. In order to be transferable, the letter of credit must state that it is transferable. In this case, the beneficiary may request the nominated bank, now renamed the transferring bank, to make part of the credit available to a second beneficiary (the manufacturer or supplier). The nominated or transferring bank will then, against conforming documents, pay the supplier its price, pay the beneficiary its profit, and then recover the full purchase price from the issuing bank.

56 The effecting of payment can take many forms in different permutations. It may be simply to pay on delivery of conforming documents (sight payment). It can also be to pay some time after the delivery of conforming documents (deferred payment). It may further be to accept a term bill of exchange against delivery of conforming documents and to pay the bill of exchange (the banker's acceptance) when it matures. Finally, it may be to "negotiate" the conforming documents. The awkward term "negotiate" means to purchase the conforming documents from the beneficiary (of course at a discount) and then to present them for payment to the issuing bank. 
The letter of credit may, finally, provide for reimbursement of the nominated bank by a bank other than the issuing bank known as the reimbursing bank. Such reimbursement may or may not be covered by special rules emanating from the ICC.A failure by the reimbursing bank to reimburse the nominated bank, however, does not relieve the issuing bank from reimbursing the nominated bank (in this context - the claiming bank)..$^{57}$

Payment in a letter of credit transaction is often deferred. This can be done by making use of a so-called deferred payment credit in which the bank's undertaking is to pay, not on acceptance of conforming documents, but at a specified time thereafter (for example " 90 days after the date of the bill of lading"). Deferment can also be done by making use of an acceptance credit (as opposed to the payment credit described above). In this case, the bank's undertaking is to accept a term bill of exchange against delivery of conforming documents and to pay it on maturity. This type of arrangement may enable the extension of credit to the buyer. Moreover, since the seller who has delivered conforming documents acquires an unconditional right against the bank to be paid on a specific future date, and banks are normally reliable debtors, the seller is typically able to be paid much earlier by discounting his right to payment to a forfaiter or factor.

\section{The OFAC sanctions (linked to ships) affecting payment by letter of credit}

Towards the end of the SDN list, there is a separate section relating to vessels (ships and aircraft), which first appeared in 2008, now comprising some 21 pages, introduced as follows:

\footnotetext{
"Blocked vessels have been segregated into a separate section of the SDN List, below. Except in limited circumstances, financial institutions are instructed to reject any funds transfer referencing a blocked vessel and must notify OFAC, preferably via facsimile with a copy of the payment instructions that funds have been returned to the remitter due to the possible involvement of a blocked vessel in the underlying transaction. See 31 C.F.R. $\$$ 501.604(b)(1). Financial institutions should contact OFAC's Compliance Outreach and Implementation Division for further instructions should the name of a blocked vessel appear in shipping documents presented under a letter of credit or if noticed
}

57 See art 13 of the UCP 600 . 
in a documentary collection. Blocked vessels must themselves be physically blocked should they enter U.S. jurisdiction. Freight forwarders and shippers may not charter, book cargo on, or otherwise deal with blocked vessels". ${ }^{58}$

The list contains more than 500 vessels $^{59}$ carrying flags of, inter alia, the DPRK, Iran, Syria, Cuba, Mongolia, Malta, Panama, Trinidad and Tobago, Russia, Comoros, Cyprus, Liberia, Sierra Leone and Tanzania. One inscription on the list, selected randomly, reads, for example:

"IRAN YOUSHAT Bunkering Tanker Iran flag; Additional Sanctions Information

- Subject to Secondary Sanctions; Vessel Registration Identification IMO 8319952 (vessel) [IRAN] (LinkedTo:ISLAMIC REPUBLIC OF IRAN SHIPPING LINES)" ${ }^{60}$

As is clear from this example, the listing contains not only the name of the ship (Iran Youshat), but also the permanent non-variable IMO registration number (8319952) in order to address the problem of ship-owners changing the names of their vessels to circumvent sanctions. ${ }^{61}$ For this reason, a letter of credit may require that the bill of lading should contain the IMO number. Bills of lading, however, often do not and shippers sometimes refuse to state this number on the bill of lading. ${ }^{62}$ In this respect, it would accordingly appear that maritime practice and sanctions may not be well-synchronised as yet. ${ }^{63}$

The practical implication of this is, inter alia, that no US bank, whether involved in a letter of credit transaction as issuing bank, nominated bank, confirming bank, transferring bank or reimbursing bank, will process payment of a letter of credit should any of the vast array of documents presented in terms of

58 https://www.treasury.gov/ofac/downloads/sdnlist.pdf (19-3-2019). This list is updated almost daily. The listed vessels appeared on pages $1238-1259$ of the list as it was when accessed. The italics are ours.

59 It is of interest to note, moreover, that certain logistics companies have lists of their own naming additional ships that are not on the OFAC list. See, in this regard, the list of Expeditors at https://www.expeditors.com/vessels-ofconcern which contains a further 33 ships.

60 https://www.treasury.gov/ofac/downloads/sdnlist.pdf (19-3-2019) 1248.

61 Strong and Herd (n 48). See also n 49 above in relation to the IMO number.

62 See "Requirement of IMO Number in Bill of Lading" https://shippingandfreightresource.com/requirement-imo-number-bill-lading/ (21-3-2019).

63 See in general on this non-alignment, Stewart and Osborne "Discussion paper: UN maritime sanctions and the International Maritime Organisation” Project Alpha, Centre for Science and Security Studies, King's College London (15 November 2018) https://projectalpha.eu/discussion-paper-un-maritime-sanctions-and-theinternational-organisation/ (21-3-2019). 
the credit contain a reference to a so-called blocked vessel. For it to do so would be unlawful under US law. Translated into the language of the South African law of contract, performance by a US bank of its obligations in terms of the letter of credit transaction is legally impossible. The permutations are many. We restrict ourselves to a few examples.

A letter of credit is issued by a US bank in favour of a South African beneficiary. The letter of credit is confirmed by a South African bank. The beneficiary presents conforming documents to the South African bank. The documents, however, indicate that, in the final leg of the voyage, the goods were carried on an OFAC-listed vessel. If the South African bank pays the beneficiary, it will not be reimbursed by the US bank. If it does not pay the beneficiary, however, it will be in breach of its contractual obligations towards the beneficiary in terms of its confirmation of the letter of credit because the performance of its obligations is not unlawful in South African law. Hence, it should be possible for the beneficiary to enforce payment against the South African confirming bank.

(ii) A letter of credit is issued by a US bank in favour of a South African beneficiary. The beneficiary presents conforming documents to a South African nominated bank. The documents, however, indicate that, in the final leg of the voyage, the goods were carried on an OFAC-listed vessel. If the South African bank pays the beneficiary, it will not be reimbursed by the US bank. Since the nominated bank has made no payment undertaking towards the beneficiary, there is no reason why it should pay the beneficiary.

(iii) An acceptance letter of credit is issued by a US bank in favour of a South African beneficiary. The beneficiary presents conforming documents to the South African nominated bank together with a bill of exchange drawn on the nominated bank payable 90 days after acceptance. The documents, however, indicate that, in the final leg of the voyage, the goods were carried on an OFAC-listed vessel. If the South African nominated bank pays the beneficiary in accordance with its obligations under the bill of exchange (accepted by the nominated bank), it will not be reimbursed by the US bank. However, in accordance with South African law it will be contractually bound to pay the beneficiary, or any subsequent holder 
(who may have purchased it in a discounting transaction) on maturity of the bill of exchange.

A South African bank issues a letter of credit in favour of a Ghanaian beneficiary. The letter of credit, however, is payable in US dollars and, accordingly, requires the services of a US correspondent bank. The documents indicate that the goods were carried on an OFAC-listed vessel. The US bank will be legally unable to process the transaction. Performance will accordingly be impossible irrespective of the fact that the sale may well be perfectly legal both in South African and in Ghanaian law.

Against this background, it is clear that banks involved in letter-of-credit transactions in various capacities may find themselves in a precarious position. In an article focusing on the risks relating to traditional trade financing instruments (the main one of which is the letter of credit) in the context of sanctions and the fight against international financial crime, Marxen identifies certain "unintended consequences of increased and stricter compliance rules". He states, inter alia:

"The compliance matrix is ... expanded by extraterritorial application of laws and regulations by some countries, most notably the United States of America (also referred to as long-reach or long-arm approach or legislation) in matters of, inter alia, sanctions. By treating transactions that are nominated in US-Dollars, in some cases irrespective of where contract formation takes place, where goods or services are exchanged or delivered, and where parties are domiciled, to be subject to US-American law, the United States of America, effectively, imposes its own compliance expectations onto the global financial network and international banking and trade". ${ }^{64}$

One of the "unintended consequences", it is submitted, has been the emergence of so-called "sanctions clauses" being included in letters of credit. ${ }^{65}$

64 Marxen "Traditional trade finance instruments a high risk? A critical view on current international initiatives and regulatory measures to curb financial crime" in Hugo (ed) Annual Banking Law Update (2018) 161 177-178 (footnotes omitted). See also Stanton "North Korea:The myth of maxed-out sanctions" 2 Fletcher Sec Rev (2015) 20 23, who refers to "the Treasury Department's global reach". At 24, he puts it thus: “Treasury has harnessed its regulatory power of the dollar system to ferret out money laundering and terrorist financing within the millions of transactions flowing through the system. By availing themselves of the dollar system, banks subject themselves to Treasury's regulatory authorities, and undertake obligations to know their customers, report large cash transactions, and report suspicious activity. Treasury's authorities allow it to gather financial intelligence, to block assets involved in illicit activity, and even to restrict or even block a foreign bank's access to the dollar system".

65 According to the ICC Banking Commission (n 47) par 2.1, sanction clauses flow from a concern of banks "about the implications of sanctions for their own obligations" and in order to "notify their counterparties, whether correspondent banks or beneficiaries" of these implications. 
In a recently released guidance paper, the ICC Banking Commission quotes the following three clauses: ${ }^{66}$

(a) "Presentation of document(s) that are not in compliance with the applicable anti-boycott, anti-money laundering, anti-terrorism, anti-drug trafficking and economic sanctions laws and regulations is not acceptable. Applicable laws vary depending on the transaction and may include United Nations, United States and/or local laws". ${ }^{67}$

(b) "[Bank] complies with the international sanction laws and regulations issued by the United States of America, the European Union and the United Nations (as well as local laws and regulations applicable to the issuing branch) and in furtherance of those laws and regulations, [Bank] has adopted policies which in some cases go beyond the requirement of applicable laws and regulations. Therefore [Bank] undertakes no obligation to make any payment under, or otherwise to implement, this letter of credit (including but not limited to processing documents or advising the letter of credit), if there is involvement by any person (natural, corporate or governmental) listed in the USA, EU, UN or local sanctions lists, or any involvement by or nexus with Cuba, Sudan, Iran or Myanmar, or any of their governmental agencies". ${ }^{68}$

(c) "Trade and economic sanctions ('sanctions') imposed by governments, government agencies or departments, regulators, central banks and/or transnational organizations (including the United Nations and European Union) impact upon transactions involving countries, or persons resident within countries currently including [long list of countries follows]..... . Issuing bank and all of its related bodies corporate might be subject to and affected by, sanctions, with which it will comply. Please contact issuing bank for clarification before presenting documents to issuing bank ... or undertaking any dealings regarding this credit involving countries or persons affected by sanctions. Issuing bank is not and will not be liable for any loss or damage whatsoever associated directly or indirectly with the application of sanctions to a transaction or financial service involving issuing bank. Issuing bank is not required to perform any obligation under this credit which it determines in its discretion will, or would be likely to, contravene or breach any sanction. This clause applies notwithstanding any inconsistency with the current edition of the ... [UCP]". ${ }^{69}$

66 See n 47 above. These three types of clauses are also considered in Reed Smith "Sanctions clauses - safeguarding payment under letters of credit” (11 January 2012) https://www.reedsmith.com/en/perspectives/2012/01/ sanctions-clauses--safeguarding-payment-under-letters-of-credit (19-8-2018).

67 par 3.1 (a).

68 par 3.1 (b) (our italics).

69 par 3.1 (c) (our italics). 
A sanctions clause that effectively states simply that the issuing bank is bound by the laws to which it is subject, is uncontroversial but also meaningless. In addition, such laws will necessarily apply irrespective of whether they, or one or some of them, may be in conflict with provisions of the UCP 600. As pointed out above, the UCP constitutes no more than terms of contract and cannot trump prescriptive law. Hence, sanctions clause (a) quoted above is unproblematic, but it also serves no purpose, except perhaps of drawing attention to the existence of sanctions laws.

As pointed out in the Guidance Paper, however, sanctions clause (b) quoted above is more problematic. This clause draws attention to the fact that the bank has adopted (internal) policies relating to sanctions which may go further than the applicable laws and regulations. Although not stating so explicitly, the logical interpretation of the clause must be that the bank may also decline to pay or process the transaction if it would be inconsistent with its own internal policies, irrespective of the law. The beneficiary is not privy to these internal policies and is therefore unable to assess the strength of the bank's undertaking. Moreover, the nominated and/or confirming bank similarly have no knowledge of these internal policies and, accordingly, cannot assess accurately whether they will be reimbursed. It is suggested, furthermore, that the mandate given by the issuing bank to the nominated bank relating to a letter of credit containing such a clause may indeed fail to meet the requirements of a valid contract. This is a complex question, the answer to which may well differ from jurisdiction to jurisdiction. A detailed consideration of it falls outside the scope of this paper. We limit ourselves to stating that, in our view, true consensus may be a problem ${ }^{70}$ and so may lack of certainty. ${ }^{71}$ Moreover, the issuing bank's obligation could conceivably be seen as subject to a potestative condition ("I will perform if I want to"), in which case there is no valid contract in South African law. ${ }^{72}$

All that is said above in relation to clause (b) is applicable mutatis mutandis to clause (c), which allows the issuing bank not to pay or process payment on the

\footnotetext{
70 See Van Huyssteen, Lubbe and Reinecke Contract General Principles (2016) par 2.21.

71 Van Huyssteen et al (n 70) par 8.2-8.2.

72 Van Huyssteen et al (n 70) par 9.151; De Wet andVan Wyk De Wet en Yeats Die Suid-Afrikaanse Kontraktereg en Handelsreg (1978) 135.
} 
basis of a determination "in its discretion" that such payment would contravene or would be likely to contravene sanctions. Against this background, the Guidance Paper concludes by recommending "that banks should refrain from issuing trade-finance-related instruments that include sanctions clauses that purport to impose restrictions beyond, or conflict with, the applicable statutory or regulatory requirements". ${ }^{73}$ It also advises parties involved in letter-of-credit transactions to "refrain from bringing into question the irrevocable, independent nature of the credit ..., the certainty of payment or the intent to honour obligations". ${ }^{74}$

Despite the afore-mentioned ICC Guidance Paper which dates back to 2014, however, sanctions clauses akin to (b) and (c) quoted above are still encountered often. The Banking Commission of the ICC is, for example, currently in the process of drafting an official opinion to a query from a bank lamenting "a very unfortunate trend"75 of rejections of documents by issuing banks in terms such as the following:

"Note the documents have been rejected and returned to you by courier because of local and international laws and regulations and internal policy for AML/CTF and foreign sanctions in accordance with our L/C terms". ${ }^{76}$

This "trend" is diametrically opposed to conventional letter-of-credit law, in terms of which documents can only be returned if they are in fact not in conformity with the requirements of the letter of credit. ${ }^{77}$ In the case on which the opinion was sought, it was well established that the documents were not rejected for being non-conforming. The requester for the opinion puts it thus:

"When questioned the issuing bank confirmed that its refusals were not caused by
the presentations being non-compliant with the terms and conditions of any credit.
Rather, follow up responses from the bank appear to indicate that the refusals were due

73 ICC Banking Commission (n 47) par 4.1.

74 ICC Banking Commission (n 47) par 4.2.

75 See ICC Banking Commission Document 470/1280 (09-09-2018) 2.

76 ibid (the italics are ours). The sanctions clause concerned reads as follows: "Our bank process [sic] transactions in accordance with local and international laws and regulations, and reserve [sic] the right to comply with foreign sanctions as well. Consequently documents issued by or showing any involvement of parties sanctioned by any competent authority or contained any information thereon [sic] might not be processed by our bank at our [sic] sole discretion and without any liability on our [sic] part".

77 See art 15 of the UCP 600 read with art 7,14 and 16. 
to regulatory concerns, which were then subsequently clarified to relate to internal policy and risk concerns, rather than regulatory".

At the time of the drafting of this contribution, the opinion sought had not yet been released by the ICC Banking Commission but, in light of its Guidance Paper, it is likely to be highly critical of this approach (or trend).

It is clear, however, that the once highly secure letter-of-credit business has become significantly riskier in these times of targeted financial sanctions. Beneficiaries are less certain of being paid and banks which have paid or have committed themselves to pay, may not be able to recover the money paid. A US bank that refuses to pay or reimburse due to the fact that the documents disclose that the goods were carried on a listed vessel will be able to rely on the fact that it would be illegal for it to pay or reimburse. Non-US banks, outside of the United States, however, will not be able to rely on such a defence. Hence, such banks which have bound themselves contractually to pay (for example, by confirming a letter of credit or by accepting a term bill of exchange against delivery of conforming documents) can conceivably be sued by beneficiaries should they refuse to pay. The legal risk of non-compliance with sanctions has clearly become significant in the context of the document-rich letter-of-credit trade. Moreover, even where no American bank is involved, non-compliance with OFAC sanctions holds, for the banks involved, enormous reputational risks which can lead to a prohibition of maintaining correspondent accounts within US financial institutions, thereby cutting off access to the US dollar payment systems as well as business in the United States generally. ${ }^{78}$

This has led to "the value of the documentary letter of credit ... as an instrument of trade being reduced" 79 and to an increase in clean (that is nondocumentary) trading terms which, ironically, may be counterproductive. Marxen puts it thus:

78 Carter and Farha (n 9) 319; Stanton (n 64) 24.

79 Newsletter Clyde\&Co “Trade sanctions - Clyde \& Co seminar tests market impact” (May 2012) https://www.clydeco.com/uploads/Files/Publications/2012/CC001134_SanctionsUpdate_Trade_Sanctions_ Seminar_03.05.12.pdf (31-3-2019), which quotes the following comment by an attendee: "Banks are wary. That's the reality of doing international business. Often you could trade legally but are constrained operationally because the bank won't take the risk". 
"Changing and expanding financial crime legislation makes it increasingly difficult and cumbersome for banks and other parties involved in international trade and international trade finance to comply with applicable laws... In many cases, banks have responded by limiting their risk exposure ... Significant de-risking decisions have been reported in international banking and trade finance which, in turn, have contributed to the emergence of clean payment trading terms in international contracts. Clean payment transactions, regrettably, deprive banks of transactional oversight and therefore limit their capabilities of identifying and reporting financial crime. The unintended consequences of de-risking and clean payment terms run counter to the initial aim of increasing customer and transactional monitoring and insight to scrutinise data for signs of financial crime", ${ }^{80}$

\section{CONCLUSION}

A benign and non-cynical view of the sanctions reflected on above may be that they have been designed and implemented in furtherance of world peace. In this context, it is of interest to note that both the League of Nations and the ICC arose from the grim aftermath of the devastation of World War 1, with express desires by the two bodies to further world peace. For the League of Nations, this was its "principal mission" ${ }^{1}$ - and one could probably say that the same is true of the UN, although the preamble of its Charter goes significantly wider. ${ }^{82}$ Their

$80 \quad$ (n 64) 183.

81 https://en.wikipedia.org/wiki/League_of_Nations (7-5-2019).

82 See https://www.un.org/en/sections/un-charter/preamble/index.html. It reads as follows: "WE THE PEOPLES OF THE UNITED NATIONS DETERMINED to save succeeding generations from the scourge of war, which twice in our lifetime has brought untold sorrow to mankind, and to reaffirm faith in fundamental human rights, in the dignity and worth of the human person, in the equal rights of men and women and of nations large and small, and to establish conditions under which justice and respect for the obligations arising from treaties and other sources of international law can be maintained, and to promote social progress and better standards of life in larger freedom, AND FOR THESE ENDS to practice tolerance and live together in peace with one another as good neighbours, and to unite our strength to maintain international peace and security, and to ensure, by the acceptance of principles and the institution of methods, that armed force shall not be used, save in the common interest, and to employ international machinery for the promotion of the economic and social advancement of all peoples, HAVE RESOLVED TO COMBINE OUR EFFORTS TO ACCOMPLISH THESE AIMS. Accordingly, our respective Governments, through representatives assembled in the city of San Francisco, who have exhibited their full powers found to be in good and due form, have agreed to the present Charter of the United Nations and do hereby establish an international organization to be known as the United Nations". 
success in this regard has not been unmitigated. ${ }^{83}$ The introductory phrase of the preamble to the ICC's constitution, on the other hand, states that its fundamental objective "is to further the development of an open world economy with the firm conviction that international commercial exchanges are conducive to both greater global prosperity and peace amongst nations". ${ }^{84}$ Its focus, accordingly, was to facilitate international trade in the belief that this would, indirectly, contribute towards world peace. Its trade facilitation work has been successful in many respects, especially in the harmonisation of trade practices and law $^{85}$ as well as dispute resolution. This gives rise to the profound irony that trade facilitation and sanctions stand in direct contrast to one another. Especially in relation to widereaching national sanctions imposed by powerful States such as the US, we suggest that it is important continually to interrogate whether those sanctions are indeed contributing towards world peace. ${ }^{86}$

The wide reach of current targeted financial sanctions also poses the question whether they still serve the purpose of targeting guilty leaders without disastrous consequences for innocent citizens. We are inclined to the view that the nature and multitude of the actors involved (even the ship carrying the goods) cannot but lead to significant collateral consequences resulting in suffering for millions of innocent people. It should be noted in this regard that international human-

83 as emerges movingly from the final verse of the lyrics of the Irish folk song Green Fields of France which, by occasion, has been described as "probably the finest anti-war song ever written" (http://www.irish-folk-songs.com/ the-green-fields-of-france-lyrics-and-chords.html (7-5-2019): "Well Will Mc Bride I can't help wonder why - Do those that lie here know why did they die - And did they believe when they answered the call - Did they really believe that this war would end war - Well the sorrow the suffering the glory the pain - The killing the dying was all done in vain - For young Willy Mc Bride it all happened again - And again, and again, and again, and again" (the hyphens are ours).

84 http://www.iccwbo.org/constitution/Article1 (7-5-2019). On its official web page, under the heading "Who we are" the following is stated: "ICC is the world business organization, enabling business to secure peace, prosperity and opportunity for all” (https://iccwbo.org/about-us/ (7-5-2019)). This focus on peace is also evident from the title of the PhD thesis of Tomasot Selling Peace: The History of the International Chamber of Commerce, 19191925 (2015) Georgia State University (full text accessible at https://scholarworks.gsu.edu/cgi/viewcontent. cgi?article $=1045 \&$ context=history_diss). See also Hugo "Non-governmental initiatives towards the harmonisation of international trade law” 2003 Journal of Juridical Science 142149.

85 For reflections on some of its successes specifically in relation to the harmonisation of international trade law, see Hugo (n 46) 1-20.

86 There appears to be mounting pressure internationally against specific US sanctions. INSTEX (for "Instrument for Supporting Trade Exchanges"), a special purpose vehicle registered in France with Germany, France, and the UK as initial shareholders, aimed at countering recent US sanctions against Iran, was set up recently after a joint announcement in November 2018 "affirming the EU's commitment to maintaining financial channels with Iran". See, in this regard, https://www.gtreview.com/news/mena/analysis-will-europes-new-iran-payment-mechanismwork/ (9-5-2019). 
rights-based litigation flowing from sanctions aimed at terrorists is growing. ${ }^{87}$ This development requires serious reflection.

On the financial side, one inevitable consequence is the rising costs of banking and trade financing due to the massive burden on banks which have to scrutinise documents in order to comply with sanctions emerging from the UNSC and individual countries and which may differ in important respects. Moreover, there is a growing expectation that banks should go even further (with further cost implications) by embarking on "vessel tracking" before processing payment. ${ }^{8}$

This tension between trade facilitation and the intended or unintended consequences of sanctions is reminiscent of the conflict between two imperatives that followed in the wake of the $9 / 11$ terrorist attacks and the ensuing counterterrorism sanctions regime. At the occasion of receiving an honorary degree from the University of Tilburg in 2002, Kofi Annan, the then UN Secretary-General of the United Nations, cautioned that we are facing a nearly unsolvable conflict between protecting the traditional civil liberties of citizens and ensuring their safety from catastrophic terrorist attacks. ${ }^{89}$ Soon after the first UN sanctionsbased counter-terrorism measures were adopted, it became clear that the swift and universal condemnation of the methods and practices of terrorism incited an over-zealous response by some States which threatens the very civil liberties they are supposed to protect. As indicated above, this invited corrective action to restore the balance. The question is whether we have reached the same point with sanctions impacting on international sales and the processing of payments in respect of transactions involving targeted ships.

87 See for instance the Sayadi $v$ Belgium communication before the UN Human Rights Committee, CCPR/ C/94/D/1472/2006 (29 December 2008); Kadi \& Al Barakaat International Foundation v Council of the European Union and Commission of the European Communities, European Court of Human Rights, Grand Chamber, C-401/05 P and C-415/05 (2008); Al Jedda v United Kingdom, European Court of Human Rights, Grand Chamber, Appl no 27021/08 (7 July 2011); Nada v Switzerland European Court of Human Rights, Grand Chamber ditto Appl no 10593/08 (12 September 2012); European Commission and Others $v$ Yassin Abdullah Kadi, European Court of Human Rights, joined cases C-584/10 P and C-593/10 (18 July 2013).

88 See Updates “Tracking vessel voyages” Jan 2018 Documentary Credit World 4.

89 Available at www.un.or/press/en/2002/SGSM8515.doc.htm (28-05-2019). 